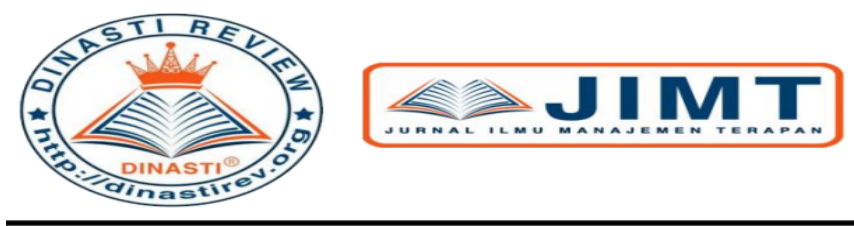

+62 878-9658-6407

087896586407

https://dinastirev.org/JIMT editor@dinastirev.org

\title{
STRATEGI PENGEMBANGAN SUMBER DAYA MANUSIA GUNA MENINGKATKAN KINERJA KARYAWAN MELALUI ANALISIS SWOT DIVISI CASH PROCESSING CENTER PADA PT ADVANTAGE SCM KOTA PADANG
}

\section{Letnan Dalimunthe}

Universitas Putra Indonesia "YPTK” Padang

ARTICLE INFORMATION

Received: $11 / 09 / 2019$

Revised: 21/09/2019

Issued: 28 September 2019

(filled in by Editor)

Corresponding Author:

Letnan Dalimunthe

E-mail: masroiniritonga@gmail.com

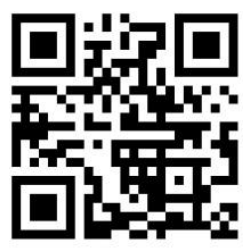

DOI:10.31933/JIMT
Abstrak: Penelitian ini bertujuan untuk menentukan strategi untuk mengembangkan sumber daya manusia PT Advantage SCM Cabang Padang dengan menganalisis kekuatan, kelemahan, peluang dan ancaman yang dimiliki perusahaan. Metode penelitian yang digunakan adalah Metode Kualitatif Matrik SWOT, Tabel IFAS,EFAS. Dari perhitungan tabel IFAS kekuatan lebih rendah dari pada kelemahan, serta perhitungan dari tabel EFAS peluang lebih besar dari ancaman sehingga titik diagram terdapat pada titik kuadan 1 stability. Adapun strategi yang digunakan adalah Strategi tepat yang harus diterapkan oleh PT Advantage SCM Cabang Semarang berdasarkan ANALISIS SWOT yaitu dengan menerapkan Strategi SO (Strength-Opportunities) strategi ini digunakan untuk memanfaatkan kekuatan perusahaan guna menangkap peluang perusahaan yang ada.

Kata Kunci: Analisa SWOT, IFAS EFAS, Strategi Pengembangan SDM.

\section{PENDAHULUAN}

Dalam era globalisasi seperti sekarang ini, perkembangan dunia usaha di Indonesia sangatlah pesat seiring dengan pertumbuhan di segala bidang di mana ditandai dengan adanya persaingan antar perusahaan yang sangat terbuka dan ketat, dalam kondisi seperti ini perusahaan dituntut untuk mengadakan penyesuaian-penyesuaian dalam segi yang ada dalam perusahaan tersebut. Terbatasnya sumber daya manusia yang ada, perusahaan diharapkan dapat mengoptimalkannya sehingga tercapai tujuan dan kemajuan. Oleh karena itu dalam era sekarang ini dimana teknologi dan peradapan sudah sangat maju menuntut sumber daya manusia yang kompeten yang memiliki semangat dan kedisiplinan yang tinggi dalam menjalankan peran dan fungsinya baik untuk individual maupun tujuan organisasinya. Maju tidaknya suatu negara tergantung dari kemampuan sumber daya manusianya.

Menyadari pentingnya peran sumber daya manusia dalam perkembangan dunia kerja dalam interaksinya dengan faktor modal, material, metode, mesin dan kegiatan bisnis perusahaan maka perlu mengelola sumber daya manusia sebaik mungkin.Hal ini, sebagaimana yang dikemukakan oleh Mathis dan Jackson $(2006$, h2) bahwa "Sumber daya 
manusia adalah rancangan sistem - sistem formal dalam sebuah organisasi untuk memastikan penggunaan bakat manusia secara efektif dan efisien guna mencapai tujuan organisasi. Hal ini menjadi konsenkuensi bagi lembaga untuk membuat penyesuaian antara SDM dengan fasilitas-fasilitas tersebut, lewat pelatihan dan pengembangan yang sesuai dengan kondisi dan kebutuhan lembaga.Pengembangan SDM merupakan upaya yang terencana dan dilakukan secara berkesinambungan untuk meningkatkan kompetensi pekerja dan untuk kerja organisasi melalui program pelatihan, pendidikan dan pengembangan. Setidaknya ada 5 (lima) usaha yang direkomendasikan dalam pengembangan sumber daya manusia yaitu : pelatihan, pendidikan, program pembinaan, recruitmen, perubahan system Program pengembangan SDM akan menjadi efektif apabila terlebih dahulu perusahaan mampu mengumpulkan dan menganalisiskeadaan, kondisi dan kebutuhan SDM saat ini dan dimasa yang akan datang, sehingga program pengembangan yang di buat benar - benar mengantar menuju kesuksesan. Wirawan (2015:193 ) menjelaskan bahwa pengembangan sumber daya manusia adalah program pembelajaran yang disengaja dan dilaksanakan dalam waktu tertentu dengan tujuan antara untuk mengembangkan pengetahuan, kompetensi sikap, motivasi dan perilaku sumber daya manusia dan tujuan akhirnya untuk mengembangkan kinerja sumber daya manusia dan kinerja organisasi. Salah satu perusahaan yang saat ini sedang berkembang dan membutuhkan strategi pengembangan SDM nya adalah PT Advantage SCM yang berpusat di kawasan Jakarta dan memiliki beberapa cabang di kota - kota yang terletak strategis. Perusahaan yang bergerak dibidang jasa cash manajemen perbankan, berperan sangat penting sebagai penghimpun dan penyalur dana yang asalnya dari masyarakat. Aktifitas layanan jasa lalu lintas pembayaran dan peredaran uang. Jasa yang diberikan ke nasabah selalu disesuaikan dengan kebutuhan masyarakat.

Demi mencapai tujuan untuk menjadi perusahaan jasa pengelola keuangan yang baik, PT Advantage SCM sangat memerlukan dukungan baik dari segi lingkungan internal maupun eksternal agar tujuan perusahaan tersebut dapat terwujud.Namun pada kenyataannya selama beberapa tahun terakhir PT. Advantage SCM mengalami penurunan layanan yang di tandai dengan semakin berkurangnya kelolaan mesin ATM yang dapat dilihat dari Grafik dibawah ini.

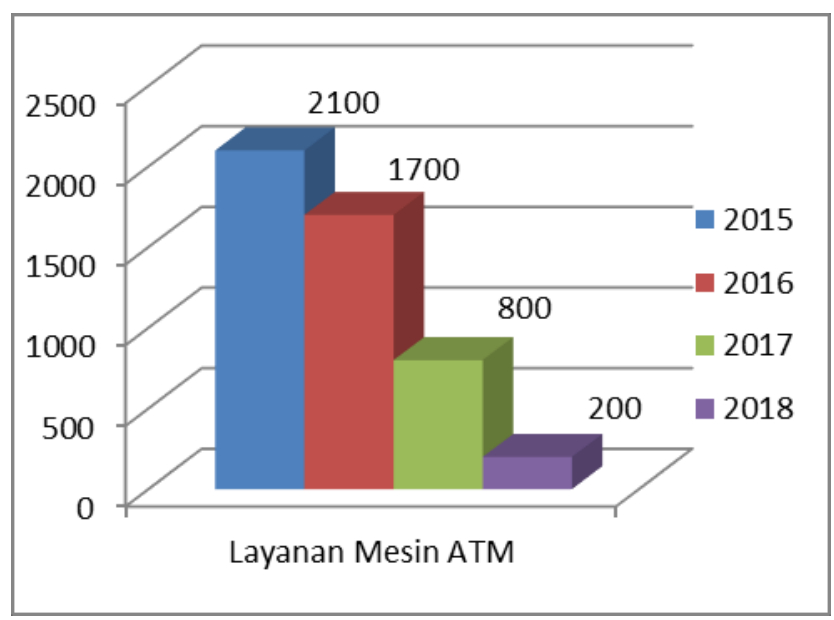

Gambar 1. Jumlah Jasa Layanan ATM

Perlu di ketahui perusahaan yang sejenis dalam hal mengelola peredaran uang di Indonesia sudah semakin meningkat jumlahnya, sehingga perusahaan perlu melakukan inovasi guna meningkatkan kinerja karyawan. Kualitas \& m kuantitas adalah salah satu bukti terjadinya penurunan layanan tersebut.Pengurangan keloaan mesin ATM seperti 
grafik di atas terjadi akibat banyaknya ketidakpuasan masyarakat pengguna fasilitas mesin ATM karena uang yang di tarik dari mesin ATM masih tercampur fisik uang jelek atau uang tidak layak edar (UTLE). Hal tersebut terjadi karena proses sortasi uang dilakukan oleh cashier training yang notabenya belum menguasai prosedur pemrosesan uang. Adanya peraturan dari Bank Indonesia untuk kategori sortasi uang yang menjadikan uang tersebut masih campur. Komposisi karyawan yang kurang menguasai penggunaan mesin hitung yang merupakan fasilitas pendukung kerja berdampak pada hasil yang didapat tidak sesuai dengan kapasitas mesin tersebut. Seharusnya mesin Glory dalam 1 jam nya bisa menghasilkan 30.000 lembar, tetapi yang didapat hanya $15.000 \mathrm{lbr} / \mathrm{jam}$. Tidak seimbang antara uang masuk dan hasil proses. Pemisahan tahun emisi uang yang dibagi menjadi 3 kategori yaitu : emisi 2016, 2014, dan 2004 semakin memperlambat kinerja cashier ditambah tidak semua demoninasi uang bisa di proses pada mesin hitung Glory dan hanya bisa dilakukan dengan cara manual, ketrampilan dan kecepatan kerja tangan sangat dibutuhkan. Kurang maksimalnya hasil sortasi manual hal tersebut diatas yang mempengaruhi dan mengakibatkan terlambatnya pengantaran Deposit / setoran uang ke Bank Indonesia karena jumlah yang harus disetorkan belum terpenuhi, truck pengangkut uang tiba di loket penyetoran melebihi dari waktu yang telah dtentukan. Kurang maksimalnya hasil sortasi manualDalam hal ini sangat bertolak belakang dengan fungsi divisi Cash Procesing Centre ( CPC ) yang merupakan jantung sekaligus nyawa perusahaan dalam mengelola, menyediakan \& memastikan tersedianya kualitas Uang ULE dan UTLE yang dapat diterima serta digunakan oleh masyarakat banyak.

Adanya permintaan dari Bank pun untuk penyetoran Uang ULE / UTLE ke Bank Indonesia yang telah ditentukan masih belum dapat terpenuhi karena kurang maksimalnya kinerja karyawan sehingga perusahaan tidak dapat memenuhi permintaan Bank tersebut. Dan ini bisa berdampak pula saat Truck yang akan mengantarkan Uang ke Bank Indonesia menjadi terlambat dari waktu yang sudah ditentukan. Jika hal itu terus dibiarkan, maka nilai kepercayaan pihak Bank / Klien terhadap perusahaan akan semakin berkurang bahkan ditinggalkan oleh Pihak Bank / Klien. Sebagaimana yang dikemukanan oleh Khaerun Syah sebagai Supervisor CPC bahwa : "Saat ini perusahaan membutuhkan karyawan yang banyak namun jug harus didukung dengan kemampuan yang handal dalam pengoperasian mesin, dengan demikian perusahaan dapat memenuhi permintaan klien.

Dari uraian diatas untuk menghadapi persaingan yang tinggi dan mempertahankannya, perusahaan perlu melakukan usaha meningkatkan kinerja organisasi dalam lingkungan internal dan eksternal agar perusahaan dapat beroperasi secara efektif dan efisien, strategi yang digunakan adalah dengan menggunakan Analisis SWOT.

Rangkuti (2015:19), Analisi SWOT (Strenghts, Weaknesses, Opportunities, Threats) merupakan salah satu alat bantu yang digunakan untuk mengembangkan strategi yang berlandaskan pada situasi di sekeliling perusahaan yang mempengaruhi kinerja perusahaan. Faktor ini diklarifikasikan sebagai faktor internal dan eksternal perusahaan yaitu hubungan antara organisasi dan masyarakat yang menciptakan dan mendukungnya.Didalam masyarakat terdapat faktor berpegaruh organisasi.

\section{KAJIAN PUSTAKA}

\section{Sumber Daya Manusia}

Sumber Daya Manusia adalah penduduk yang siap, mau dan mampu memberikan sumbangan terhadap usaha untuk mencapai tujuan organisasi.Dalam ilmu kependuduk-an, 
konsep sumber daya manusia ini dapat disejajarkan dengan konsep tenaga kerja yang meliputi angkatan kerja dan bukan angkatan kerja.Angkatan yang bekerja disebut juga dengan pekerja.Organisasi pada dasarnya merupakan kerja sama antara dua orang atau lebih dalam rangka mencapai suatu tujuan. Organisasi adalah kumpulan orang, proses pembagi-an kerja antara orang-orang tersebut dan adanya system kerja sama atau system sosial diantara orang-orang tersebut.

Dalam mencapai tujuan, organisasi memerlukan berbagai macam sumber daya. Mulai dari sumber daya manusia, peralatan, mesin, keuangan, dan sumber daya informasi. Setiap sumber daya memiliki tugas dan fungsinya masing - masing. Sebagai suatu system sumber daya tersebut akan berinteraksi dan saling bekerja sama sehingga tujuan dapat tercapai dengan efektif dan efisien.

Dengan berpijak pada pendekatan sistem, manajemen sumber daya manusia merupakan bagian dari sebuah sistem yang lebih besar yaitu organisasi.Oleh karena itu upaya-upaya sumber daya manusia hendak dievaluasi berdasarkan kontribusinya, berdasarkan produktifitas organisasi.Dalam prakteknya model manajemen sumber daya manusia merupakan sebuah system terbuka yang terbentuk dari bagian-bagian yang saling terikat.Setiap organisasi baik organisasi perusahaa, sosial, pemerintahan mempunyai tujuan yang dapat dicapai melalui pelaksanaan pekerjaan tertentu, dengan mampergunakan sumber daya yang ada pada organisasi.Dan yang paling penting dalam mencapai organisasi adalah sumber daya manusia.

Sumber daya manusia sebagai salah satu sumber daya yang ada dalam organisasi memegang peranan penting dalam keberhasilan pencapaian tujuan organisasi.Berhasil atau tidaknya tergantung pada kemampuan sumber daya manusia dalam menjalankan tugas dan fungsinya, manusia selalu berperan aktif dan selalu dominan dalam setiap aktifitas organisasi, karena manusia menjadi perencana, pelaku, sekaligus penentu terwujudnya tujuan organisasi.

Manajemen sumber daya manusia kedudukannya sangat penting bagi organisasi. Oleh karena itu dalam mengelolanya, mengatur dan memanfaatkan sumber daya manusia akan berjalan sesuai apa yang diharapkan. Sehingga dapat berfungsi secara produktif untuk tercapainya tujuan organisasi.

\section{Analisa SWOT}

Menurut Fredy Rangkuti (2004:18) menjelaskan bahwa analisis SWOT adalah identifikasi berbagai faktor secara sistematis untuk merumuskan strategi perusahaan. Analisis ini didasarkan pada logika yang dapat memaksimalkan kekuatan (strength) dan peluang (opportunities), namun secara bersamaan dapat meminimalkan kelemahan (weakneses) dan ancaman (threats). Proses pengambilan keputusan sinergi selalu berkaitan dengan pengembangan misi, tujuan, strategi dan kebijakan perusahaan. Dengan demikian perencanaan strategi harus menganalisa faktor-faktor strategi perusahaan (kekuatan, kelemahan, peluang, ancaman).

Matrik SWOT adalah alat yang dipakai untuk menyusun faktor-faktor strategi perusahaan. Matrik ini dapat menggambarkan secara jelas bagaimana peluang dan ancaman eksternal yang dihadapi perusahaan disesuikan dengan kekuatan dan kelemahan yang dimilikinya. Matrik ini dapat menghasilkan empat sel kemungkinan alternatif strategi (Freddy Rangkuty, 2009: 31) 


\begin{tabular}{|c|c|c|}
\hline IFAS & $\begin{array}{l}\text { Strengths (S) } \\
\text { Tentukan } \\
\text { faktor-faktor } \\
\text { kekuatan internal }\end{array}$ & $\begin{array}{l}\text { Weaknesses (W) } \\
\text { Tentukan } \\
\text { faktor- } \\
\text { internal }\end{array}$ \\
\hline Opportunities (O) & Strategi SO & Strategi WO \\
\hline $\begin{array}{l}\text { Tentukan faktor: } \\
\text { faktor } \\
\text { eksternal }\end{array}$ & $\begin{array}{l}\text { Buat strategi disini } \\
\text { yang menggunakan } \\
\text { kekuatan untuk } \\
\text { memanfaatkan } \\
\text { peluang }\end{array}$ & $\begin{array}{l}\text { Buat strategi disin } \\
\text { meminimalkan } \\
\text { kele untuk } \\
\text { memanfaatkan pelu }\end{array}$ \\
\hline Treats (T) & Strategi ST & Strategi WT \\
\hline $\begin{array}{l}\text { Tentukan faktor- } \\
\text { faktor ancaman } \\
\text { eksternal }\end{array}$ & $\begin{array}{l}\text { Buat strategi disini } \\
\text { yang menggunakan } \\
\text { kekuatan untuk } \\
\text { mengatasi ancaman }\end{array}$ & $\begin{array}{l}\text { Buat strateg } \\
\text { disini meminimalkar } \\
\text { kelemaha menghindar } \\
\text { ancaman }\end{array}$ \\
\hline
\end{tabular}

Gambar 2. Diagram Matrik SWOT

1. Strategi SO

Strategi ini dibuat berdasarkan jalan pikiran perusahaan, yaitu dengan memanfaatkan seluruh kekuatan untuk merebut dan memanfaatkan peluang sebesar-besarnya.

2. Strategi ST

Ini adalah strategi dalam menggunakan kekuatan yang dimiliki perusahaan untuk mengatasi ancaman.

3. Strategi WO

Strategi ini diterapkan berdasarkan pemanfaatan peluang yang ada dengan cara meminimalkan kelemahan yang ada.

4. Strategi WT

Strategi ini didasarkan pada kegiatan yang bersifat defensif dan berusaha meminimalkan kelemahan yang ada serta menghindari ancaman.

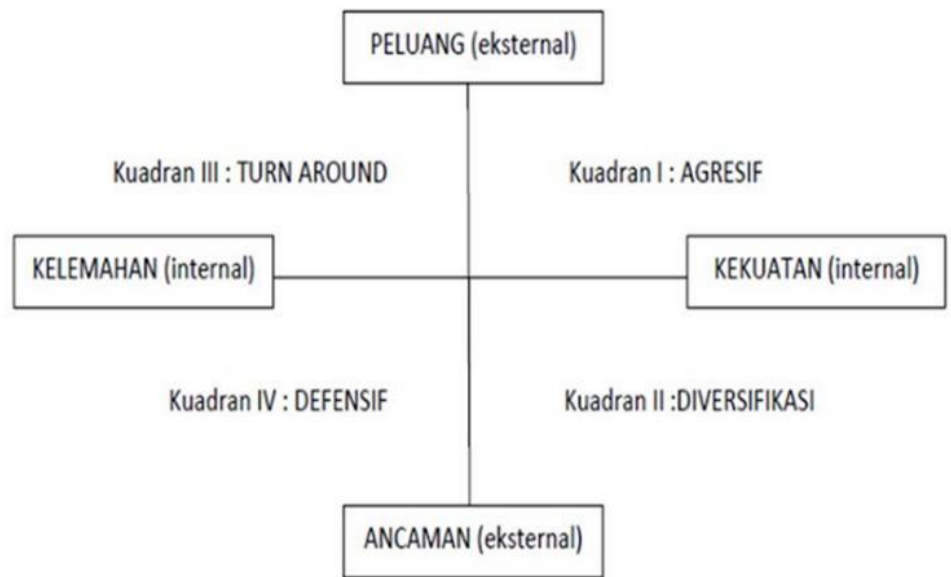

Kuadran I :

Gambar 3. Diagram Analisis SWOT

Merupakan situasi yang sangat menguntungkan, perusahaan memiliki peluang dan kekuatan strategi yang diterapkan yaitu mendukung kebijakan pertumbuhan yang agresif.

Kuadran II :

Terdapat ancaman, namun masih memiliki kekuatan dari segi internal, strategi yang 
diterapkan menggunakan kekuatan untuk memnfaatkan peluang jangka panjang Kuadran III : dengan cara strategi diversifikasi (produk/pasar).

Perusahaan menghadapi peluang pasar yang sangat besar, tetapi ada beberapa kendala / kelemahan internal. Strategi yang harus diterapkan dengan meminimalkan Kuadran IV :

masalah internal agar dapat merebut peluang pasar.

Merupakan situasi yang sangat tidak menguntungkan, perussahaan menghadapi berbagai ancaman dan kelemahan internal

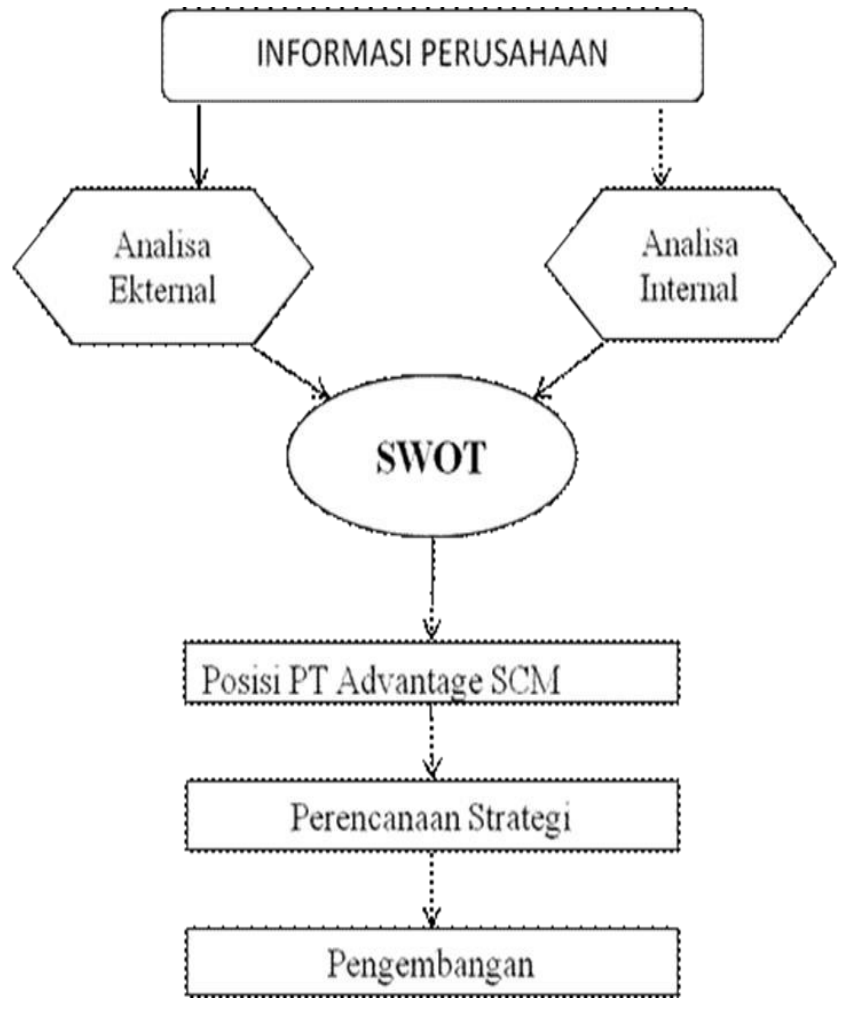

Gambar 4. Alur Pemikiran

\section{METODE PENELITIAN}

Penentuan informan dalam penelitian ini menggunakan metode Purpose dan Snowball sampling, yaitu penentuan sample dengan pertimbangn tertentu yang mula-mula jumlahnya kecil, kemudian membesar sesuai dengan kebutuhan untuk mendapatkan data penelitian yang lengkap. Untuk mendapatkan informasi mengenai perusahaan PT Advantage SCM ini penulis melakukan wawancara kepada Bapak Khaerunsyah selaku Supervisor kanto cabang Padang. Informan untuk penelitian awal penulis hanya melakukan wawancara pada satu orang informan. Selanjutnya dari informan yang didapat, penulis akan melakukan wawancara lanjutan agar informasi dapat digali lebih dalam sehingga dapat diperoleh data yang lengkap untuk dianalisis. Tidak menutup kemungkinan informan dalam penelitian ini akan bertambah lagi untuk mengembangkan informasi. Pada penelitian kulitatif, seperti yang telah dikemukakan oleh Sugiyono (2013), sampel sumber data pada tahap awal memasuki lapangan dipilih orang yang memiliki power dan otoritas pada situasi sosial atau obyek yang diteliti, sehingga mampu "membuka pintu" kemana saja peneliti akan melakukan pengumpulan data. Siapa yang dijadikan sampel sumber data, dan berapa jumlahnya dapat diketahui setelah peneliti selesai. Jadi tidak bisa disiapkan sejak awal atau dalam proposal. Penelitian ini dibuat untuk mengetahui posisi perusahan menggunakan Analisa SWOT 
pada divisi Cash Procesing Centre PT Advantage SCM cab. Padang. Sebagai penentuan strategi pengembangan sumber daya manusia guna meningkatkan kinerja karyawan. Jenis penelitian kali ini, yang akan digunakan adalah penelitian kualitatif diskriptif. Sugiyono (2011:15), menyimpulkan bahwa metode penelitian kualitatif adalah metode penelitian yang berlandaskan pada filsafaat postpositivisme, digunakan untuk meneliti pada kondisi obyek yang alamiah, (sebagai lawannya eksperimen) dimana peneliti adalah sebagai instrument kunci, pengambilan sampel sumber data dilakukan secara purposive dan snowbaal, teknik pengumpulan dengan trianggulasi (gabungan), analisis data bersifat induktif/kualitaif, dan hasil penelitian kualitatif lebih menekankan makna dari pada generalisasi.

\section{HASIL DAN PEMBAHASAN}

\section{Kekuatan (Strength)}

1. Kualitas Hasil Proses PT Advantage SCM Cabang Padang

2. Penetapan harga Layanan PT Advantage SCM Cabang Padang

3. Nyaman

4. Menguntungkan

5. Aman

6. Lokasi Perusahaan

7. Pelayanan Konsumen

\section{Kelemahan (Weaknesses )}

1. Sumber Daya Manusia

2. Kurang Promosi

3. Budaya Karyawan

4. Tidak adanya pengembangan karyawan

5. Lambatnya Proses Sortasi

\section{Peluang ( Opportunties )}

1. Memiliki undang-undang yang mendukung

2. Promosi Melalui Media Elektronik

3. Teknologi

4. Citra Perusahaan di Mata Konsumen

5. Permintaan Pasar.

\section{Ancaman ( Threats )}

1. Banyaknya Pesaing

2. Produk Jasa

3. Kebijakan Pemerintah

4. Penarikan layanan kerja sama oleh bank

5. Kenaikan harga barang ( inflasi )

Identifikasi faktor internal dan eksternal pada PT Advantage SCM Cabang Padang adalah sebagai berikut :

\section{Matrik IFAS}

Setelah faktor-faktor strategis internal suatu perusahaan diidentifikasi, suatu tabel IFAS (Internal Factor Srategic Analysis Summary) disusun untuk merumuskan faktor-faktor strategis internal tersebut dalam kerangka Strength and Weakness perusahaan. Penentuan 
bobot berdasarkan pengaruh faktor-faktor terhadap posisi strategis perusahaan, didasarkan pada penyebaran angket kepada responden dari PT Avantage SCM, yaitu supervisor, team leader dan karyawan, dengan memberikan bobot pada masing-masing faktor dengan skala mulai dari 1,0 (paling penting) sampai 0,0 (tidak penting), semua bobot tersebut jumlahnya tidak boleh melebihi skor total 1,00. Penentuan rating diberikan dengan meminta bantuan Branch Manager PT Advantage SCM Cabang Padang, yaitu Bapak Dedek Setyawan yang dianggap mengetahui pengetahuan menyeluruh mengenai manajemen perusahaan baik internal dan eksternal perusahaan.

Tabel 1 . Faktor Strategi Internal PT Advantage SCM Cabang Padang (IFAS)

\begin{tabular}{|l|l|l|l|}
\hline Faktor-faktor Strategis Internal & $\begin{array}{l}\text { Bobot } \\
\text { Item }\end{array}$ & Rating & $\begin{array}{l}\text { Bobot } \\
\text { item X Ra }\end{array}$ \\
\hline Kekuatan ( Strength ) & & & \\
\hline $\begin{array}{l}\text { Kualitas Hasil Proses Standart Bank } \\
\text { Indonesia }\end{array}$ & 0,126 & 4 & 0,504 \\
\hline Penetapan harga layanan bersaing & 0,119 & 3 & 0,357 \\
\hline Nyaman, menguntungkan, Aman & 0,112 & 3 & 0,3 \\
\hline Lokasi perusahaan Strategis & 0,120 & 3 & 0,36 \\
\hline Kualitas pelayanan memuaskan & 0,118 & 4 & 0,472 \\
\hline Jumlah & & & $\mathbf{2 , 0 3}$ \\
\hline Kelemahan ( Weaknesses ) & & & \\
\hline Sumber Daya Manusia Kurang & 0,086 & 2 & 0,172 \\
\hline Kurangnya Promosi & 0,072 & 2 & 0,144 \\
\hline Budaya Karyawan & 0,087 & 2 & 0,174 \\
\hline $\begin{array}{l}\text { Tidak adanya pengembangan } \\
\text { Karyawan }\end{array}$ & 0,083 & 2 & 0,166 \\
\hline Lambat proses sortasi & & & 0,148 \\
\hline Jumlah & 0,074 & 2 & $\mathbf{0 , 8 0}$ \\
\hline Jumlah Kekuatan dan Kelemahan & $\mathbf{1 , 0 0}$ & & $\mathbf{2 . 8 3}$ \\
\hline
\end{tabular}

Sumber : Data primer yang diolah, 2018

Total bobot item $\mathrm{x}$ rating pada tabel 1 untuk faktor kekuatan bernilai 2,03 dan faktor kelemahan bernilai 0,80 . Nilai tersebut yang digunakan sebagai acuan titk kondisi perusahaan saat ini.

\section{Matrik EFAS}

Sebelum membuat matrik faktor strategi eksternal, kita perlu mengetahui terlebih dahulu Faktor Strategi Eksternal (EFAS) yaitu peluang dan ancaman yang mungkin dapat mempengaruhi perusahaan dimasa yang akan datang. Pemberian bobot masing-masing faktor mulai dari 1,0 (sangat penting) sampai dengan 0,0 (tidak penting). Nilai rating dapat diberikan mulai skala 4 (outstanding) sampai dengan 1 (poor). Pemberian nilai rating untuk faktor peluang bersifat positif (peluang yang lebih besar diberi rating +4 , tetapi jika peluangnya kecil diberi rating +1 . Pemberian nilai rating ancaman adalah kebalikanya.

Tabel 2. Faktor Strategi Eksternal PT Advantage SCM Cabang Padang (EFAS)

\begin{tabular}{|l|l|l|l|}
\hline Faktor-faktor Strategis Internal & $\begin{array}{l}\text { Bobot } \\
\text { Item }\end{array}$ & Rating & $\begin{array}{l}\text { Bobot } \\
\text { item }\end{array}$ \\
\hline Peluang ( Opportunties ) & & & \\
\hline Peraturan dari Pemerintah & 0,121 & 3 & 0,363 \\
\hline
\end{tabular}




\begin{tabular}{|l|l|l|l|}
\hline Promosi Media Elektronik & 0,115 & 3 & 0,345 \\
\hline Perkembangan Teknologi & 0,124 & 4 & 0,496 \\
\hline Citra Perusahaan & 0,120 & 3 & 0,36 \\
\hline Permintaan Pasar & 0,123 & 4 & 0,492 \\
\hline Jumlah & & & $\mathbf{2 , 0 5}$ \\
\hline Ancaman ( Threats ) & & & \\
\hline $\begin{array}{l}\text { Keberadaan Pesaing perusahaan yang } \\
\text { Sejenis }\end{array}$ & 0,073 & 2 & 0,146 \\
\hline $\begin{array}{l}\text { Produk Jasa yang lebih murah } \\
\text { Kebijakan pemerintah menaikkan } \\
\text { harga BBM }\end{array}$ & 0,076 & 3 & 0,084 \\
\hline $\begin{array}{l}\text { Penarikan Layanan Kerja Sama oleh } \\
\text { Bank }\end{array}$ & 0,074 & 2 & 0,228 \\
\hline Kenaikan harga barang ( inflasi ) & 0,085 & 2 & 0,17 \\
\hline Jumlah & & & $\mathbf{0 , 9 4}$ \\
\hline Jumlah Kekuatan dan Kelemahan & $\mathbf{1 , 0 0}$ & & $\mathbf{3 , 0 1}$ \\
\hline
\end{tabular}

Sumber : Data primer yang diolah, 2018

Total bobot item x rating pada tabel 4.2 untuk faktor peluang bernilai 2,05 dan faktor ancaman bernilai 0,94 . Nilai tersebut yang digunakan sebagai acuan titk kondisi perusahaan saat ini.

Penilaian terhadap faktor internal dan eksternal yang dimiliki PT Advantage SCM Cabang Padang dapat diperoleh dari total skor yang merupakan jumlah hasil perkalian bobot dan rating pada tabel diatas 1 dan tabel 2 untuk faktor ekternal total skor 2.83 dan faktor internal memperoleh total skor 3,01. Tahap selanjutnya berdasarkan total skor yang diperoleh perusahaan dalam tabel faktor startegi internal dan eksternal tersebut dapat digambarkan posisi perusahaan untuk menerapkan strategi yang sesuai dengan kondisi saat ini yaitu dengan menggunakan Diagram SWOT.

Berdasarkan Tabel 1 dan 2 diketahui nilai Kekuatan (Strength) dan Kelemahan (Weaknesses) selisih (+) 1,22 dan nilai Peluang (Opportunties) dan Ancaman (Threats) selisih (+) 1.11.

\section{KESIMPULAN}

Dari pembahasan yang telah diuaraikan serta berdasarkan data yang penulis peroleh dari penelitian sebagaimana yang dibahas dalam skripsi maka dapat ditarik kesimpulan sebagai berikut :

1. Berdasarkan dari hasil analisis faktor internal yaitu didapat dari penjumlahan rating dan faktor kekuatan dan kelemahan perusahaan menunjukkan bahwa kualitas pelayanan berpengaruh besar terhadap kelangsungan hidup perusahaan. Saat ini perusahaan telah melayani bank-bank besar di padang salah satunya adalah Bank BCA, jenis layanan yang dikelola PT Advantage SCM Cabang Padang adalah pick up service, untuk pengisian atm dan kelolaan pick up service area semarang masih dipegang oleh perusahaan pesaing. Kedepanya dengan terus memberikan service terbaik diharapkan PT Advantage SCM Cabang Padang bisa mendapatkan kesempatan untuk mengambil alih kelolaan area semarang tersebut. Sedangkan untuk faktor kelemahan PT Advantage 
SCM Cabang Padang adalah dari segi sumber daya manusianya.

2. Berdasarkan hasil analisis faktor eksternal yaitu didapat dari penjumlahan rating dan faktor peluang dan ancaman peluang tertinggi terdapat pada semakin tinggi nya permintaan pasar yang dipengaruhi oleh semakin tinggi nya minat masyarakat untuk mendapatkan pelayanan yang cepat dan tidak mengantri, pada masa saat ini masyarakat lebih banyak melakukan transaksi dengan menggunakan mesin atm dari pada pergi ke kantor cabang bank konvensional. Sedangkan untuk faktor ancaman terdapat pada keberadaan pesaing sesama perusahaan jasa, hal ini menunjukkan bahwa perusahaan jasa PT Advantage SCM Cabang Padang harus siap dengan berbagai ancaman eksternal yang ada saat ini .

3. Hasil analisa data mengenai posisi perusahaan dengan menggunakan analisis SWOT menunjukkan bahwa PT Advantage SCM Cabang Padang saat ini berada dalam fase pertumbuhan usaha. Strategi tepat yang harus diterapkan oleh PT Advantage SCM Cabang Padang berdasarkan ANALISIS SWOT yaitu dengan menerapkan Strategi SO (Strength - Opportunities)Strategi ini digunakan untuk memanfaatkan kekuatan perusahaan guna menangkap peluang perusahaan yang ada. Meliputi

a. Memanfaatkan ijin yang dikeluarkan sebaik mungkin dengan pemenuhan layanan sesuai SLA

b. Memanfaatkan sosial media yang ada sebagai sarana promosi masyarakat umum

c. Dengan adanya peralatan mesin yang canggih diharapkan dapat memenuhi target yang telah ditentukan

d. Memperkuat citra perusahaan dengan mengatasi komplain dari klien hingga tuntas.

\section{DAFTAR RUJUKAN}

Khasandra, M.Fidel. 2017. Analisis SWOT Bisnis

Laundry UD Rafa Laundry Klindocare di Duri Provinsi Riau( Studi Formulasi Strategi Bersaing ).Universitas Riau

Sugiarti. 2013. Analisis SWOT sebagai upaya meningkatkan kinerja produksi menuju usaha yang berkelanjutan (Studi pada UKM Batik di Kampung Batik Laweyan Surakarta).Politeknik Negeri Semarang

Tampiko, Hendaru. 2014. Strategi Pengembangan Sumber Daya Manusia (SDM) Koperasi industri Kakao Sumatra Utara. Institut Teknologi Inonesia

Nur Irawan, Mohamad Rizal. 2016. Analisis SWOT untuk menentukan strategi konpeitif pada PD BPR Bank Daerah Lamongan.Universitas Islam Lamongan

Yon Ismaya,Jeni dan Pribadiono, NoviandariIndah. 2017. Analisa SWOT untuk mengetahui positioning perusahaan dalam memntukan strategi pengembangan sumber daya manusia pada UD Rumekso di Mojokerto.Universitas Bhayangkara Surabaya

Ginting, A. (2016). Perumusan Strategi Perusahaan PT X menggunakan Matriks Evaluasi Faktor. Jurnal Sistem Teknik Industri

Zulkarnaen, H. O., dan Sutopo. (2013) Analisis Strategi Pemasaran pada Usaha Kecil Menengah (UKM) Makanan Ringan (Studi Penelitian UKM Snack Barokah di Solo).

Diponegoro Journal of Management. 2(3):

$1-13$

Rangkuti, F, 2005, Analisis SWOT Teknik Membedah Kasus Bisnis, PT Gramedia Pustaka Utama, Jakarta

Amila Khusnita. 2011. Analisis SWOT dalam penentuan Strategi Bersaing (studi pada PT Bank Syariah Kantor Cabang Syariah Jember)

Bambang Wahyudi. 2011. Manajemen Sumber Daya Manusia. Bandung : Sulita Miftachul Tuwin. 2015. Analisa SWOT untuk Mengetahui Kondisi Sumber Daya Manusia Dalam Rangka Peningkatan Daya Saing Pada CV INDOSAE GPS TRACKER di Surabaya. 